\title{
Fourth ventricular solitary fibrous tumor: a case report and review of the literature
}

\author{
Congli Wang ${ }^{1 *}$, Varsha Manucha', Scott Faro², Michael Weaver ${ }^{3}$ and Abir L Mukherjee ${ }^{1}$
}

\begin{abstract}
Introduction: Solitary fibrous tumors of the central nervous system usually present as dura-based masses and clinically resemble meningiomas. There are very few reported cases of intra-ventricular solitary fibrous tumors, particularly in the fourth ventricle.

Case presentation: Our patient was a 52-year-old African-American man, who presented to our facility with a two-month history of progressive weakness and numbness in all extremities. A computed tomography scan and brain magnetic resonance imaging scan revealed a homogeneous, avidly enhancing $4.5 \times 3.7 \times 2.7 \mathrm{~cm}$ fourth ventricular mass, with compression of adjacent medulla and cerebellum and extension into the foramen of Luschka. Our patient underwent a suboccipital craniotomy and resection of the tumor. A histological examination showed a spindle cell neoplasm with prominent collagenized stroma. The neoplastic cells were strongly and diffusely positive for CD34, vimentin and BCl-2, and negative for S-100, CD99 and epithelial membrane antigen. The molecular immunology Borstel-1 (MIB-1) proliferation index was low (1\%). CD31 immunostain highlighted the endothelial cells but the spindle cells were negative. Reticulin stain demonstrated a moderate reticulin network but individual cells were not invested by reticulin fibers. The histological features and immunoprofile was consistent with a solitary fibrous tumor.

Conclusions: In the central nervous system, solitary fibrous tumors are usually indolent tumors, with only rare examples showing hypercellularity and increased mitotic activity; features that were absent in our patient's case. We present an uncommon central nervous system neoplasm in a rare location. Although uncommon, solitary fibrous tumors should be included in the differential diagnosis of intra-ventricular tumors in adults.
\end{abstract}

Keywords: Fourth ventricle, Intraventricular, Solitary fibrous tumor

\section{Introduction}

Solitary fibrous tumors (SFTs) were originally described in pleura and subsequently in soft tissue and many other organs including the central nervous system. SFTs of the central nervous system are rare entities, usually presenting as dura-based masses predominantly in the posterior fossa and spinal region [1]. SFTs are composed of spindle cells in a collagenized stroma with characteristic immunohistochemical features: diffuse and strong reactivity to CD34, positive for vimentin, and often immunoreactive to CD99 and Bcl-2 [1]. Intra-ventricular SFTs are rare, and only six cases have been reported in the fourth ventricle [2-7].

\footnotetext{
* Correspondence: congli.wang@tuhs.temple.edu

'Department of Pathology and Laboratory Medicine, Temple University Hospital, 3401 North Broad Street, Philadelphia, PA 19140, USA

Full list of author information is available at the end of the article
}

\section{Case presentation}

Our patient was a 52-year-old African-American man who presented to our facility with a two-month history of progressive weakness and numbness in all extremities. A computed tomography (CT) scan and a brain magnetic resonance imaging (MRI) scan revealed a $4.5 \times 3.7$ $\times 2.7 \mathrm{~cm}$, homogeneous, avidly enhancing mass located in the fourth ventricle, compressing adjacent medulla and cerebellum and extending into the foramen of Luschka (Figure 1). Angiography demonstrated multiple dysplastic-appearing branches from the right posterior inferior cerebellar artery supplying the neoplasm.

Our patient underwent a suboccipital craniotomy and resection of the tumor. During the operation, a cavitron ultrasonic surgical aspirator as well as bipolar cautery and suction were used to debulk the tumor, followed by a combination of RHOTON ${ }^{\mathrm{m}}$ dissectors as well as microscissors

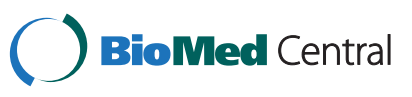



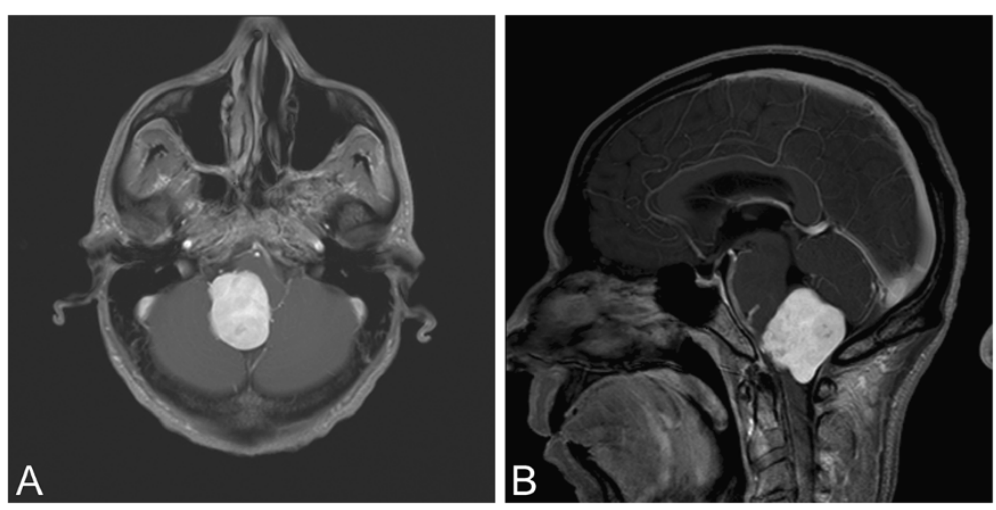

Figure 1 Contrast-enhanced T1-weighted axial (A) and sagittal (B) magnetic resonance imaging scans showing a homogenous mass located in the fourth ventricle.

to separate the tumor. The entire tumor was successfully removed.

Histological examination showed a spindle cell neoplasm with prominent collagenized stroma (Figure 2A). Mitotic figures were not readily found and the molecular immunology Borstel-1 (MIB-1) proliferation index was low (1\%). Meningothelial whorls and psammoma bodies were absent. The neoplastic cells were strongly and diffusely positive for CD34 (Figure 2B), vimentin and Bcl-2 (Figure 3A); no immunoreactivity with S-100, CD99 and epithelial membrane antigen (EMA) was detected. A CD31 immunostain highlighted the endothelial cells but not the spindle tumor cells. A moderate reticulin network was demonstrated by reticulin staining, but individual cells were not invested by reticulin fibers (Figure 3B). The histological features and immunoprofile were consistent with SFT.

Our patient experienced no neurological deficit after surgery, and there were no signs of recurrence at oneyear follow-up.

\section{Discussion}

Intraventricular tumors can have a wide spectrum of differential diagnosis based on radiological and histopathological features. A bland spindle cell tumor with collagenized stroma and avid contrast enhancement initially suggested a diagnosis of fibroblastic meningioma. However the immunoprofile of the neoplastic cells was typical of a solitary fibrous tumor (negative for EMA, strongly positive for CD34, vimentin and $\mathrm{Bcl}-2$ ). In contrast, meningiomas are EMA positive and CD34 negative. Hemangiopericytomas can have histological overlap with solitary fibrous tumor, but CD34 and Bcl-2 staining is weak and patchy [8].

To the best of our knowledge, just 17 Intraventricular solitary fibrous tumors have been reported in the literature to date. Six of these tumors were located in the fourth ventricle [2-7], eight cases were in lateral ventricle location [1,9-14], one tumor located in the third ventricle [15], one case occurred in the foramina of Monro [16] and one case was a recurrent SFT arising from the falx cerebri, extending to the bilateral lateral ventricles and the third ventricle [17]. The clinical and radiological features of these tumors are given in Table 1; the immunomorphological features are given in Table 2. The age of patients ranged from 11 to 75 years old, with the vast majority being over 40 years; there was no sex predominance. Based on the available data, all the tumors were less or equal to $5.0 \mathrm{~cm}$ in their
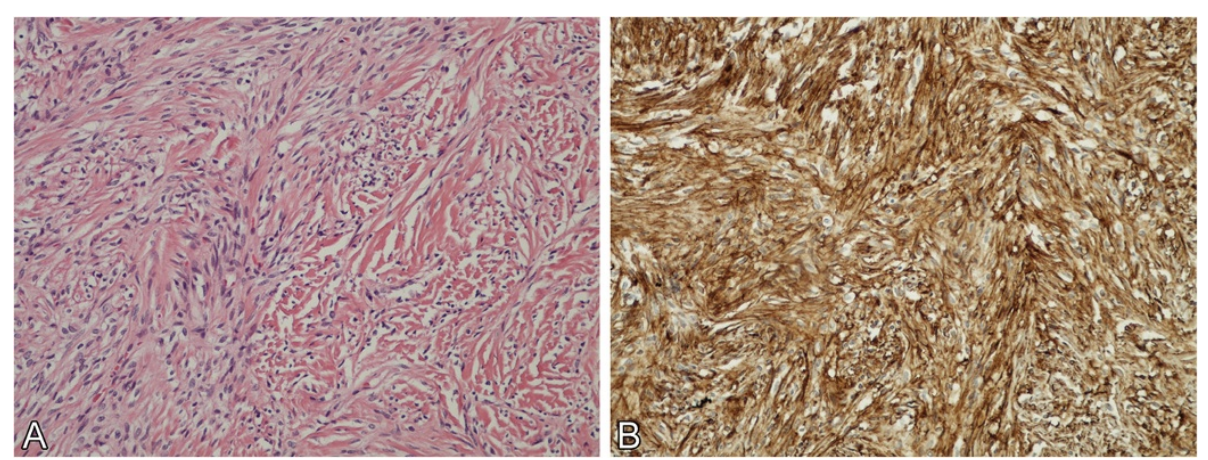

Figure 2 Photomicrographs (original magnification, 200x). (A) Bland spindle cell tumor with collagenized stroma. (B) Neoplastic cells are strongly immunoreactive to CD34. 

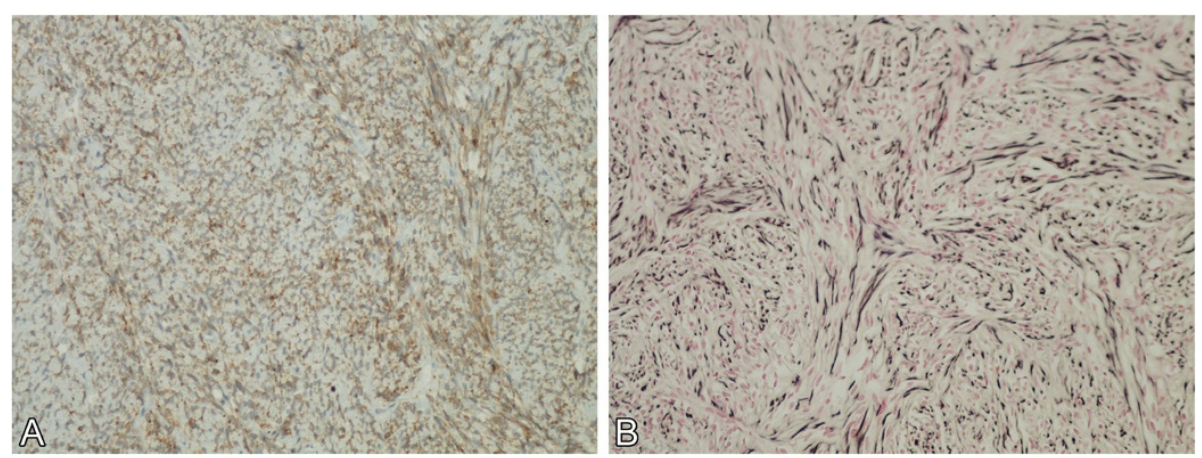

Figure 3 Photomicrographs (original magnification, 200x). (A) The tumor cells are immunoreactive to Bcl-2. (B) Neoplastic cells have moderately rich reticulin network.

Table 1 Summary of clinical and radiological features of intraventricular solitary fibrous tumors reported in the literature

\begin{tabular}{|c|c|c|c|c|c|}
\hline Reference & Age/sex & Location & $\begin{array}{l}\text { Size (greatest } \\
\text { dimension) }\end{array}$ & Imaging features & Follow-up \\
\hline Clarençon et al. [2] & $32 / F$ & Fourth ventricle & $2.5 \mathrm{~cm}$ & $\begin{array}{l}\text { MRI: hypointense T1; } \\
\text { heterogeneous- hypointense T2; } \\
\text { post-contrast enhancement }\end{array}$ & NA \\
\hline Cummings et al. [3] & $52 / \mathrm{M}$ & Fourth ventricle & NA & $\begin{array}{l}\text { MRl: homogeneous post-contrast } \\
\text { enhancement }\end{array}$ & Autopsy \\
\hline Gessi et al. [4] & $63 / F$ & Fourth ventricle & $2 \mathrm{~cm}$ & $\begin{array}{l}\text { MRI: isointense } \mathrm{T1} \text {; } \\
\text { partial post-contrast enhancement }\end{array}$ & NA \\
\hline Kim et al. [5] & $49 / F$ & Fourth ventricle & NA & MRI: dense post-contrast enhancement & $\begin{array}{l}\text { No recurrence } \\
\text { after one year }\end{array}$ \\
\hline Montano et al. [6] & $61 / \mathrm{M}$ & Fourth ventricle & NA & $\begin{array}{l}\text { MRl: hypointense T1; } \\
\text { iso-hypointense T2; } \\
\text { marked post-contrast enhancement }\end{array}$ & $\begin{array}{l}\text { No recurrence } \\
\text { after two years }\end{array}$ \\
\hline Sawauchi et al. [7] & $57 / M$ & Fourth ventricle & NA & $\begin{array}{l}\text { MRI: low intensity } \mathrm{T} 1 \text {; } \\
\text { homogeneous post-contrast } \\
\text { enhancement }\end{array}$ & NA \\
\hline Tihan et al. [1] $]^{*}$ & NA & Lateral ventricle & NA & $\begin{array}{l}\text { MRI: low density } \mathrm{T1} \text {; } \\
\text { post-contrast enhancement }\end{array}$ & NA \\
\hline Clarençon et al. [9] & $44 / F$ & Right lateral ventricle & $4.0 \mathrm{~cm}$ & $\begin{array}{l}\text { MRI: hypointense T1; } \\
\text { hyperintense T2; thin peripheral } \\
\text { enhancement of multiple confluent } \\
\text { cysts post-contrast }\end{array}$ & NA \\
\hline Liao et al. [10] & NA & Right lateral ventricle & NA & NA & NA \\
\hline Mekni et al. [11] & $40 / M$ & Right lateral ventricle & $3.5 \mathrm{~cm}$ & NA & $\begin{array}{l}\text { No recurrence } \\
\text { after three years }\end{array}$ \\
\hline Surendrababu et al. [12] & $55 / F$ & Left lateral ventricle & $5.0 \mathrm{~cm}$ & NA & $\begin{array}{l}\text { No recurrence } \\
\text { after one year }\end{array}$ \\
\hline Vassal et al. [13] & $60 / F$ & Left lateral ventricle & $5.0 \mathrm{~cm}$ & $\begin{array}{l}\text { MRI: lobulated mass; } \\
\text { homogeneous post-contrast enhancement }\end{array}$ & $\begin{array}{l}\text { No recurrence } \\
\text { after two years }\end{array}$ \\
\hline Wright et al. [14] & $11 / F$ & Right lateral ventricle & NA & NA & NA \\
\hline Koçak et al. [15] & $63 / M$ & Third ventricle & $2.5 \mathrm{~cm}$ & $\begin{array}{l}\text { MRI: isointense } \mathrm{T} 1 \text { and } \mathrm{T} 2 \text {; } \\
\text { significant post-contrast enhancement }\end{array}$ & $\begin{array}{l}\text { No recurrence } \\
\text { after three and a } \\
\text { half years }\end{array}$ \\
\hline Kinfe et al. [16] & $75 / F$ & Foramen of Monro & $2.5 \mathrm{~cm}$ & $\begin{array}{l}\mathrm{CT} \text { : Hypointense tumor at the foramina } \\
\text { of Monro; homogeneous } \\
\text { post-contrast enhancement }\end{array}$ & $\begin{array}{l}\text { No recurrence } \\
\text { after one year }\end{array}$ \\
\hline Teranishi et al. [17] & $61 / \mathrm{M}$ & & NA & & NA \\
\hline
\end{tabular}


Table 1 Summary of clinical and radiological features of intraventricular solitary fibrous tumors reported in the literature (Continued)

\begin{tabular}{llll}
\hline & $\begin{array}{l}\text { Falx cerebri, extended to } \\
\text { bilateral lateral ventricles } \\
\text { and the third ventricle }\end{array}$ & $\begin{array}{l}\text { MRI: isointense T1; } \\
\text { iso-hyperintense T2; } \\
\text { heterogeneous } \\
\text { post-contrast enhancement }\end{array}$ \\
\hline Present case & $52 / \mathrm{M} \quad$ Fourth ventricle & $\begin{array}{l}\text { Iso-hypointense T1; } \\
\text { heterogeneous T2; homogeneous } \\
\text { post-contrast enhancement }\end{array}$ & $\begin{array}{l}\text { No recurrence } \\
\text { after one year }\end{array}$ \\
\hline
\end{tabular}

*Two cases.

$\mathrm{NA}=$ not available.

$\mathrm{MRI}=$ magnetic resonance imaging.

greatest dimension. On MRI scans, the tumors are typically iso- to hypointense on T1-weighted images, and show intense and homogeneous enhancement after intravenous administration of gadolinium. Most of those SFTs had bland histological features except two tumors showed mild to marked pleomorphism $[5,11]$. Intraventricular SFTs have an indolent clinical course and excellent prognosis after surgery; however, owing to the small number of cases and limited follow-up, more data is needed to better assess the biological behavior of these tumors and the long-term outcome after treatment.

\section{Conclusions}

We report a rare case of SFT in an unusual location. Though rare, SFTs should be considered in the histological differential diagnosis of intra-ventricular tumors particularly, spindle cell tumors with collagenized stroma, along with meningioma and schwannoma.

Table 2 Summary of immunomorphological features of intraventricular solitary fibrous tumors reported in the literature

\begin{tabular}{|c|c|c|c|c|c|c|c|c|c|c|}
\hline \multirow[t]{2}{*}{ Reference } & \multicolumn{3}{|c|}{ Histologic features } & \multicolumn{7}{|c|}{ Immunohistochemical features } \\
\hline & Pleomorphism & Mitosis & Necrosis & CD 34 & $\mathrm{Bcl}-2$ & Vimentin & $S-100$ & EMA & MIB-1 & Reticulin \\
\hline Clarençon et al. [2] & NA & NA & NA & NA & NA & NA & NA & NA & NA & NA \\
\hline Cummings et al. [3] & NA & NA & NA & $\begin{array}{l}\text { Strong, } \\
\text { diffuse + }\end{array}$ & $\begin{array}{l}\text { Strong, } \\
\text { diffuse + }\end{array}$ & $\begin{array}{l}\text { Strong, } \\
\text { diffuse + }\end{array}$ & - & - & NA & NA \\
\hline Gessi et al. [4] & NA & Absent & Absent & Strong + & Strong + & Strong + & - & - & $<2 \%$ & NA \\
\hline Kim et al. [5] & Mild & Rare & NA & Diffuse + & NA & NA & - & - & $<3 \%$ & $\begin{array}{l}\text { Outlining of } \\
\text { individual cells - }\end{array}$ \\
\hline Montano et al. [6] & NA & NA & NA & + & + & + & - & - & $<1 \%$ & NA \\
\hline Sawauchi et al. [7] & NA & NA & NA & + & NA & + & NA & NA & NA & NA \\
\hline Tihan et al. [1]* & NA & NA & NA & Strong + & NA & Strong + & - & - & NA & $\begin{array}{l}\text { Overall highlighted } \\
\text { only the coarse } \\
\text { collagen background }\end{array}$ \\
\hline Clarençon et al. [9] & NA & NA & NA & Strong + & NA & NA & NA & NA & NA & NA \\
\hline Liao et al. [10] & NA & NA & NA & NA & NA & NA & NA & NA & NA & NA \\
\hline Mekni et al. [11] & Marked & 5/10 HPF & Focal & Strong + & + & Strong + & NA & NA & $<2 \%$ & NA \\
\hline $\begin{array}{l}\text { Surendrababu et al. } \\
\text { [12] }\end{array}$ & Absent & NA & NA & + & + & + & - & - & $<2 \%$ & NA \\
\hline Vassal et al. [13] & Absent & Absent & Absent & Diffuse + & NA & Diffuse + & - & - & $<2 \%$ & NA \\
\hline Wright et al. [14] & NA & NA & NA & NA & NA & NA & NA & NA & NA & NA \\
\hline Koçak et al. [15] & NA & NA & NA & Focal + & Diffuse + & NA & - & - & $1 \%$ & $\begin{array}{l}\text { Interlacing reticular } \\
\text { fibers }+\end{array}$ \\
\hline Kinfe et al. [16] & NA & NA & NA & Strong + & Strong + & Strong + & - & - & $<1 \%$ & $\begin{array}{l}\text { Rich network of } \\
\text { reticular fibers }\end{array}$ \\
\hline Teranishi et al. [17] & NA & NA & NA & Strong + & NA & + & - & - & $5 \%$ & NA \\
\hline Present case & Absent & Absent & Absent & $\begin{array}{l}\text { Strong, } \\
\text { diffuse + }\end{array}$ & $\begin{array}{l}\text { Strong, } \\
\text { diffuse + }\end{array}$ & $\begin{array}{l}\text { Strong, } \\
\text { diffuse + }\end{array}$ & - & - & $1 \%$ & $\begin{array}{l}\text { Reticulin network } \\
\text { moderate }+; \\
\text { individual cells - }\end{array}$ \\
\hline
\end{tabular}




\section{Consent}

Written informed consent was obtained from the patient for publication of this manuscript and any accompanying images. A copy of the written consent is available for review by the Editor-in-Chief of this journal.

\section{Competing interests}

The authors declare that they have no competing interests.

\section{Acknowledgements}

We acknowledge the cooperation of our patient, as well as our patient's family. This paper was not funded by any external source.

\section{Author details}

'Department of Pathology and Laboratory Medicine, Temple University Hospital, 3401 North Broad Street, Philadelphia, PA 19140, USA. ²Department of Radiology, Temple University Hospital, Philadelphia, PA, USA. ${ }^{3}$ Department of Neurosurgery, Temple University Hospital, Philadelphia, PA, USA.

\section{Authors' contributions}

CW performed the gross examination of the specimen, conceived the case report, searched the literature and drafted the manuscript. VM performed the histopathological evaluation of the slides and made substantial revisions to the manuscript. SF conducted the radiology examinations and made revisions to the manuscript. MW operated on our patient and made revisions to the manuscript. AM performed the histopathological evaluation of the slides and critical analyzed the manuscript. All authors read and approved the final manuscript.

Received: 14 November 2011 Accepted: 9 May 2012

Published: 17 July 2012

\section{References}

1. Tihan T, Viglione M, Rosenblum MK, Olivi A, Burger PC: Solitary fibrous tumors in the central nervous system. A clinicopathologic review of 18 cases and comparison to meningeal hemangiopericytomas. Arch Pathol Lab Med 2003, 127:432-439.

2. Clarençon F, Bonneville F, Sichez JP, Khalil I, Poirier J, Chiras J: Atypical location of a solitary fibrous tumor in the fourth ventricle. J Neuroradiol 2006, 33:279-280.

3. Cummings TJ, Burchette JL, McLendon RE: CD34 and dural fibroblasts: the relationship to solitary fibrous tumor and meningioma. Acta Neuropathol 2001, 102:349-354.

4. Gessi M, Lauretti L, Fernandez E, Lauriola L: Intraventricular solitary fibrous tumor: a rare location for a rare tumor. J Neurooncol 2006, 80:109-110.

5. Kim KA, Gonzalez I, McComb JG, Giannotta SL: Unusual presentations of cerebral solitary fibrous tumors: report of four cases. Neurosurgery 2004, 54:1004-1009.

6. Montano N, Doglietto F, Lauriola L, Signorelli F, Pallini R: Solitary fibrous tumor of the IV ventricle. Br J Neurosurg 2010, 24:495-496.

7. Sawauchi S, Arakawa H, Taya K, Terao T, Nakazaki H, Numoto RT, Yamaguchi Y, Hashimoto T, Yamaguchi Y, Abe T: Solitary fibrous tumor of the fourth ventricle: case report. No Shinkei Geka 2003, 31:551-555.

8. Perry A, Scheithauer BW, Nascimento AG: The imunophenotypic spectrum of meningeal hemangiopericytoma: A comparison with fibrous meningioma and solitary fibrous tumor of the meninges. Am J Surg Pathol 1997, 21:1354-1360.

9. Clarençon F, Bonneville F, Chiras J, Kujas M, Cornu P: Cystic intraventricular solitary fibrous tumor. AJNR AM J Neuroradiol 2007, 28:1205-1206.

10. Liao QL, Lai RQ: Solitary fibrous tumor of right ventricle: report of a case. Zhonghua Bing Li Xue Za Zhi 2009, 38:710-711.

11. Mekni A, Kourda J, Hammouda KB, Tangour M, Kchir N, Zitouna M, Haouet S: Solitary fibrous tumor of the central nervous system: pathological study of eight cases and review of the literature. Pathology 2009, 41:649-654.

12. Surendrababu NR, Chacko G, Daniel RT, Chacko AG: Solitary fibrous tumor of the lateral ventricle: $\mathrm{CT}$ appearances and pathologic correlation with follow-up. AJNR Am J Neuroradiol 2006, 27:2135-2136.

13. Vassal F, Manet R, Forest F, Camdessanche JP, Péoc'h M, Nuti C: Solitary fibrous tumors of the central nervous system: report of five cases with unusual clinicopathological and outcome patterns. Acta Neurochir (Wien) 2011, 153:377-384.

14. Wright DH, Naul LG, Hise JH, Bauserman SC: Intraventricular fibroma: MR and pathologic comparison. AJNR Am J Neuroradiol 1993, 14:491-492.

15. Koçak A, Cayli SR, Saraç K, Aydin NE: Intraventricular solitary fibrous tumor: an unusual tumor with radiological, ultrastructural, and immunohistochemical evaluation. Case report. Neurosurgery 2004 54:213-217.

16. Kinfe TM, Tschan CA, Stan AC, Krauss JK: Solitary fibrous tumor of the foramen of Monro. Clin Neurol Neurosurg 2008, 110:404-407.

17. Teranishi K, Yamamoto T, Nakao Y, Osada H, Wada R, Mori K: Recurrent solitary fibrous tumor of the falx cerebri with intraventricular extension. Neurol Med Chir (Tokyo) 2007, 47:269-272.

\section{doi:10.1186/1752-1947-6-205}

Cite this article as: Wang et al:: Fourth ventricular solitary fibrous tumor: a case report and review of the literature. Journal of Medical Case Reports $20126: 205$

\section{Submit your next manuscript to BioMed Central and take full advantage of:}

- Convenient online submission

- Thorough peer review

- No space constraints or color figure charges

- Immediate publication on acceptance

- Inclusion in PubMed, CAS, Scopus and Google Scholar

- Research which is freely available for redistribution 